\title{
SERGANČIŲJŲ GALVOS SMEGENŲ INSULTU GRIUVIMAI ANKSTYVUOJU REABILITACIJOS LAIKOTARPIU
}

\author{
Gabrielė Tamulytė ${ }^{1}$, Lina Varžaitytè ${ }^{2}$ \\ ${ }^{1}$ Lietuvos sveikatos moksly universiteto Medicinos akademija, \\ ${ }^{2}$ Lietuvos sveikatos mokslu universiteto Reabilitacijos klinika
}

Raktažodžiai: griuvimai po insulto, griuvimo rizika, reabilitacija, senų žmonių griuvimai, insultas, griuvimai.

\begin{abstract}
Santrauka
Tikslas - gauti naujos, mokslu pagrịstos informacijos apie senyvo amžiaus žmonių, patyrusių galvos smegenų insultą, ankstyvosios reabilitacijos galimybes, esant padidejusiai griuvimo rizikai.

Naudotasi PubMed duomenų bazių paieškos sistema. Atrinktos ir išanalizuotos nuo 2014 metų paskelbtos mokslinès publikacijos, kuriose vertinamos asmenų, patyrusių galvos smegenų insultą, reabilitacijos galimybès, esant griuvimo rizikai. Rasta 20 straipsnių, atmesta 14. Nustatytus tinkamumo kriterijus atitiko 6 straipsniai, nagrinejjantys reabilitacijos po insulto poveikị ir naudą griuvimo prevencijai. Atlikta šių straipsnių turinio analizé, kurioje apibendinami tyrimų Japonijoje, JAV, Australijoje, Kanadoje, Brazilijoje, Italijoje duomenys, atitinkantys tyrimo tikslą. Išvados - senyvo amžiaus asmenims griuvimo riziką po insulto mažintų daugiaveiksnè intervencijų programa. Efektyviausios pusiausvyros ir kompleksinès treniruotès bei Tai-chi pratimai. Naudingos robotizuotos stumdomosios vaikštynès ir elektrostimuliacija.
\end{abstract}

\section{Ivadas}

Griuvimai yra didelè visuomenès sveikatos problema. Manoma, kad kasmet pasaulyje 646 tūkstančiai griuvimų baigiasi mirtimi. Griuvimas yra antroji netyčinio susižalojimo priežastis po eismo įvykių. Tai viena iš svarbiausių senyvo amžiaus žmonių problemų, susijusi su nejudrumu, nestabilumu, šlapimo ir išmatų nelaikymu, atminties ir intelekto sutrikimu [1]. Visuose pasaulio regionuose mirštamumas dèl griuvimų didžiausias tarp vyresnių nei 60 metų asmenų [2].

Insultas yra viena iš pagrindinių negalios priežasčiu visame pasaulyje [3]. Jị patyrusiems didesnè griuvimo rizika, negu bendrosios populiacijos, tad ši aplinkybè gali sukelti nemenkus kasdienio gyvenimo ir judejjimo funkcijų sutriki- mus [4-6]. Yra duomenų, kad patyrusiųjų insultą griuvimo ir su juo susijusių sužalojimų rizika daugiau nei dvigubai didesnè, negu insulto nepatyrusių panašaus amžiaus žmonių $[5,6]$. Irodyta, kad griuvimas siejasi su mirtingumu, ligotumu, sumažèjusiu funkcionalumo lygiu ir ankstyvu patekimu i slaugos namus.

Šiuo metu yra tik žemos ir labai žemos kokybès įrodymų, kad fiziniai pratimai, kaip viena intervencija ar daugiakomponentès intervencijos dalis, ịskaitant ankstyvą vaikščiojimą ir judejimą, nestabilumo, pusiausvyros ar Tai-chi treniruotes, mažina griuvimų dažnį, bet ne bendrą po patirto insulto griuvusių žmonių skaičių. [7] Norint sukurti veiksmingą bendruomenès griuvimų prevencijos programą, būtina suprasti insultą patyrusių žmonių rizikos veiksnius ir griuvimo rizikos mažinimo galimybes.

Mokslinèje literatūroje aprašyta nemažai atvejų, kai po reabilitacijos, skirtos sumažinti griuvimų ir pargriūvančių asmenų skaičių, stebimas teigiamas efektas [8-10], tačiau vis dar trūksta informacijos apie griuvimo po patirto insulto rizikos mažinimo priemones [3].

Tyrimo tikslas - gauti naujos, mokslu pagrịstos informacijos apie senyvo amžiaus žmonių, patyrusių galvos smegenų insultą, ankstyvosios reabilitacijos galimybes, esant padidèjusiai griuvimo rizikai.

\section{Tyrimo medžiaga ir metodai}

Literatūros paieška atlikta $2020 \mathrm{~m}$. vasario mènesį, naudojant PubMed duomenų bazių paieškos sistemą. Straipsnių tinkamumo kriterijai: ne senesni nei 2014 metų; aprašyti tyrimai, nagrinejantys griuvimus po patirto insulto; atliktas asmenų, patyrusių galvos smegenų insultą, ankstyvosios reabilitacijos galimybių mažinti griuvimo riziką, vertinimas. Rasta 20 straipsnių, atmesta 14. Nustatytus tinkamumo kriterijus atitiko 6 straipsniai, nagrinejjantys reabilitacijos po insulto poveiki ir naudą griuvimo prevencijai. Tiriamosios grupès - galvos smegenų insultą patyrę senyvi žmonés, esant padidejjusiai griuvimo rizikai. Papildomai peržiūrètos ne senesnès nei 10 metų mokslinès publikacijos, susijusios 
su griuvimo po patirto insulto reabilitacijos tendencijomis pasaulyje. Atlikta atrinktų straipsnių turinio analizė ir aprašomoji duomenų analizè, kurioje apibendinami tyrimų Japonijoje, JAV, Australijoje, Kanadoje, Brazilijoje, Italijoje duomenys, atitinkantys tyrimo tikslą.

\section{Tyrimo rezultatai}

Griuvimų dažnis po patirto insulto. Griuvimus patiria apie trečdalis vyresnių nei 65 metų žmonių ir net 37,3 mln. prireikia medicininès pagalbos. Griuvimų dažnis dideja sulig amžiumi [3]. Pasaulio sveikatos organizacija pateikia duomenų, kad asmenims, ypač senyvo amžiaus, kurie griūdami susižaloja, dažnai prireikia ilgalaikès priežiūros ir hospitalizavimo. Griuvimas yra viena dažniausių komplikacijų po insulto, sukelianti įvairaus laipsnio negalią maždaug 450 tūkstančių žmonių [4,5]. Nereti atvejai (14-65\%), kai išgyvenusieji insultą pargriūva ligoninejje, tačiau dažniausiai (iki 73\%) - per pirmuosius 6 ménesius grịžę iš stacionaro ị namus [11]. Du trečdaliai pargriūva savo namuose [13-15]. Pirmają savaitę po insulto ịvyksta 7 proc. griuvimų [12].

Griuvimo rizikos veiksniai. Insulto padariniai aprèpia fizinius, pažintinius, psichologinius sutrikimus ir griuvimo riziką [11]. Daugybė kohortos ir atvejų kontrolès tyrimų nustatè, kad rizika pargriūti padidèja sutrikus pusiausvyrai, esant griuvimo baimei, turint depresijos simptomų, pargriuvus hospitalizacijos metu, esant aplinkos pavojų, šlapimo, išmatų nelaikymo problemų, motorinių ir sensorinių sutrikimų, pvz.: kojų silpnumas, jutimų praradimas, pėdų ar regos problemos [16]. Griuvimo rizika padidejja: sutrikus judèjimo funkcijai 4,3 karto, pablogejjus pusiausvyrai 3,9 karto, vartojant raminamuosius ar psichotropinius vaistus 3,2 karto, sutrikus gebejjimui apsitarnauti 2,3 karto, sergant depresija 2,1 karto, sutrikus pažinimo funkcijoms 1,8 karto, dèl patirtų griuvimų $-1,8$ karto [17]. Atliekant bendruomeninius tyrimus, geresni rezultatai matomi tada, kai kompleksiniai rizikos komponentai yra ịvertinami ir valdomi, taikant atitinkamas intervencijas $[18,19]$.

Griuvimo padariniai. Dažnai griuvimo padariniai yra sunkūs kūno sužalojimai ir psichikos sutrikimai, pablogèjusi gyvenimo kokybè, pailgèjusi hospitalizacijos trukmè, stacionarizavimas ị ilgalaikės priežiūros ar slaugos ịstaigas ir padidèjusios sveikatos priežiūros išlaidos [20]. Beveik trečdalis išgyvenusiųjų po insulto pargriuvę patiria kaulų lūžius, hematomas, minkštujų audinių sužalojimus ir funkcinès veiklos apribojimą [12]. JAV Nacionalinio sužalojimų prevencijos ir kontrolès centro duomenimis, pagrindinès hospitalizavimo dèl griuvimo priežastys yra klubo sąnario lūžiai, galvos smegenų traumos ir viršutinių galūnių sužalojimai. Patyrusiujų insultą griuvimo lūžių dažnis 4 kartus didesnis, nei bendrosios populiacijos [21]. Kai insultą išgyvenę žmonès patiria klubo sąnario lūžị, jie mažiau linkę atgauti savarankiško judejjimo galimybę, nei kiti [22]. Nerimą kelia tai, kad 34,1 proc. pargriuvusių asmenų patys negalejo atsistoti. Iš 144 insultą patyrusių tiriamųų: 126 pargriuvo, 36 patyre traumas, iš jų 4 - kaulų lūžius. Visi keturi kaulų lūžiai paretinejje kūno pusèje [8]. Kitos problemos psichosocialinès: depresija, sumažèjęs pasitikèjimas, sumenkęs orumo jausmas, sumažèjęs fizinis aktyvumas ir padidejusi priklausomybè dèl pakartotino griuvimo baimès, kuri gali sukelti veiklos ribojimą ir didesni globejjų stresą $[6,11]$.

Griuvimų prevencija yra gyvybiškai svarbi išgyvenusiems po insulto, jų globejjams ir visuomenei. Senyvo amžiaus žmonių griuvimo riziką mažina fiziniai pratimai, ypač pusiausvyros treniruotè [23].

Reabilitacijos reikšmė, mažinant griuvimų riziką. Y. Goto ir bendraautoriai (2019) aprašo tyrimą, kuriame dalyvavo 144 asmenys (vidutinis amžius 68 metai), persirgę insultu ir atitikę šiuos kriterijus: gali vaikščioti su atramine priemone ar be jos; supranta tyrimo protokolą; sutiko dalyvauti tyrime. Tiriamiesiems buvo taikoma reabilitacija suaugusiujų dienos priežiūros centre, kur jie dalyvavo 3 valandų reabilitacijos programoje 1-3 dienas per savaitę. Programą sudare 20 minučių trukmès reabilitacijos programa, apimanti vaikščiojimo, tempimo ir raumenų stiprinimo pratimus. Po programos igyvendinimo griuvimai vertinti vienerius metus, rašant griuvimų dienoraští, analizuojant griuvimų aplinkybes. Nustatyta, kad tikimybe pargriūti bent kartą metuose siekia 87,5 proc., o pargriuvus patirti lūži - 2,8 procentus. Griuvimai buvo dažnesni žiemą, dienos metu. Dažniausiai pargriūnama praradus pusiausvyrą vaikštant patalpose, ypač pakeliui ị tualetą. 34,1 proc. pargriuvusiųjų negalejo atsistoti. Atliekant 5 kartų „,sėsti-stoti“ testą, patyrusių griuvimą tiriamujjų testo atlikimo laikas buvo pastebimai ilgesnis, negu atvirkščiai $(\mathrm{p}<0,05)[8]$.

R. Taylor-Piliae ir kt. (2014) atliktame tyrime dalyvavo išgyvenusieji insultą asmenys (vidutinis amžius 70 metų). Itraukimo kriterijai: vyresni nei 50 metų; daugiau nei 3 ménesiai po insulto. Funkciné negalia vertinta taikant modifikuotą Rankino skalę, bendrosios fizinès funkcijos trumpu fizinio pajëgumo testu, pažinimo sutrikimai - trumpu protinès būklès tyrimo testu. Tyrimo dalyviai buvo stebimi trejų metų laikotarpiu. 12 savaičių taikytos intervencijos: pirmoji grupe - Yang stiliaus 24 pozų trumpalaikis Tai-chi; antroji grupè - jègos ir judesių amplitudès pratimai; trečioji grupè - ịprastinè priežiūra be intervencijų. Pirmoji ir antroji grupès lankè 1 valandos užsièmimus 3 kartus per savaitę, kontrolinè grupè kas savaitę buvo konsultuojama telefonu. Rezultatai buvo vertinami atsižvelgiant į funkcinès būklès ir gyvenimo kokybès pokyčius. Fizinių parametrų testavimui naudotas sutrumpintas fizinès funkcijos vertinimo testų 
rinkinys, griuvimo dažnio skaičiavimas ir 2 minučių ejjimo testas. Gyvenimo kokybės parametrų vertinimui naudotas sveikatos klausimynas SF-36, (trumpoji versija), Epidemiologinių tyrimų centro depresijos simptomų skalè ir Pitsburgo miego kokybės indeksas. Nustatyta, kad intervencijos metu pirmosios grupès Tai-chi dalyviai patyre dviem trečdaliais mažiau griuvimų, nei antroji ir kontrolinė grupès [24].

L. Ada su bendraautoriais (2013) atliko tyrimą, kuriame dalyvavo 102 tiriamieji, patyrę insultą (vidutinis amžius 67 metai), per pastaruosius penkerius metus baigę reabilitacijos programą ir lètai vaikštantys (galintys basomis nueiti 10 metrų, nesinaudodami pagalbinèmis priemonèmis, èjimo trukmè ilgesnè negu 9 sekundès). Taikant parengtą èjimo programą, 1-oji tiriamujų grupe treniravosi 30 minučių 3 kartus per savaitę 4 ménesius, 2-oji grupé analogiškai treniravosi du mènesius, o kontrolinei grupei intervencijos nebuvo taikomos. Griuvimai vertinti kiekvieną mènesį. Nustatyta, kad tiriamosiose grupése padidejo nueitas atstumas, tačiau griuvimų dažnis tarp grupių statistiškai reikšmingai nesiskyrè [10].

A. Mansfield ir kt. (2017) atliktame tyrime dalyvavo 31 insultą patyręs asmuo (vidutinis amžius - 60 metų), baigęs pusiausvyros lavinimo programą kaip ịprastinès stacionarinès reabilitacijos dali. Dalyviai buvo ịtraukiami ị tyrimą, jeigu: 1) galejjo savarankiškai stovèti mažiausiai 30 sekundžių; 2) galèjo nueiti naudodamiesi atramine priemone arba be jos mažiausiai 10 metrų; 3 ) baige ir toleravo pusiausvyros kontrolès vertinimą stacionarinès reabilitacijos metu; 4) buvo išrašyti iš stacionaro. Tiriamiesiems 30 minučių per dieną taikyta pusiausvyros lavinimo programa, o per likusị laiką vyko ịprastinè individualioji kineziterapija 5 dienas per savaitę. Pusiausvyros lavinimo programos sesijų skaičius ir dažnumas priklausė nuo dalyvio tolerancijos ir funkcinio lygio, reabilitacijos trukmès, dalyvio reabilitacijos tikslų ir pageidavimų. Išvykę iš stacionaro, tyrimo dalyviai 6 mènesius registravo griuvimus kasdieniame gyvenime. Griuvimu dažnis (procentais) buvo lyginamas su kontroline grupe, kuri stacionarinès reabilitacijos metu nebaigè pusiausvyros lavinimo programos. Palyginus su kontroline grupe, poveikio grupès tikimybè pargriūti buvo 2,38 karto mažesnè. Kontroliuojant stebejjimo trukmę ir motorikos sutrikimus, griuvimo dažnis pusiausvyros lavinimo grupèje buvo mažesnis, nei kontrolinèje grupèje [9].

S. Andrade ir bendraautorių (2017) atliktame tyrime dalyvavo 60 insultą patyrusių asmenų (vidutinis amžius 69 metai). Tiriamieji atsitiktine tvarka suskirstyti ị keturias grupes, kurioms taikyta skirtingų parametrų elektrostimuliacija: anodinè, katodinè, dvišalè ir transkranijinè nuolatinès srovès stimuliacija (toliau - tDCS). Dalyviai buvo įtraukiami i tyrimą, jeigu: 1) vienpusio išeminio insulto diagnozè buvo patvirtinta remiantis vaizdo tyrimais; 2) galèjo nueiti naudodamiesi atramine priemone arba be jos mažiausiai 10 metrų; 3) didelè griuvimo rizika. Kiekvienam tiriamajam taikyta 10 stimuliacijos sesijų (penkias dienas iš eilès dvi savaites). Keturių kvadratų testas, griuvimo indeksas, bendrojo stabilumo indeksas, tarptautinè griuvimų efektyvumo skalè, Berg 'o pusiausvyros skale, šešių minučių ejjimo testas ir „sėsti-stoti““ testas. Tiriamieji buvo vertinami prieš gydymą, po gydymo, po vieno ir trijų mènesių. Po gydymo visoms grupèms, išskyrus tą, kuriai taikyta tDCS, sumažèjo griuvimo rizika ir pagerèjo apatinių galūnių motoriniai ịgūdžiai. Elektrinès stimuliacijos rūšis statistiškai reikšmingo efekto griuvimų rizikos mažèjimui neturèjo. [25].

G. Morone ir kt. (2016) atliktame tyrime dalyvavo 44 asmenys (vidutinis amžius - 62 metai), patyrę galvos smegenų insultą daugiau nei prieš tris mènesius, atsitiktine tvarka suskirstyti i dvi grupes. Vienai grupei buvo taikoma tik $i$ ejimą orientuota kineziterapija, antrajai - i ejjimą orientuota kineziterapija, naudojant I-Walker robotizuotą stumdomąą vaikštynę. Dalyviai buvo ịtraukiami ị tyrimą, jeigu: 1) diagnozuotas vienpusis insultas; 2) galèjo paeiti, naudodami lygiagretes; 3) galèjo atlikti viršutinès kūno dalies judesius, įveikdami gravitaciją. Abi grupès atliko dvidešimt ị èjimą orientuotos programos sesijų, kurios truko keturias savaites. I-Walker grupe (toliau - iWG) naudojo I-Walker robotizuotą stumdomą vaikštynę. Eisena ir jos dinamika vertinta prieš gydymą, iškart po gydymo ir po 6 mènesių. Gydymo efektyvumas buvo didesnis iWG grupeje, atsižvelgiant i pusiausvyros pagerejjimą naudojant Tinetti skalę ir 10 metrų bei 6 minučių ejjimo testus. Pagerejo eisenos stabilumas ir sumažèjo griuvimų namuose kiekis [26].

\section{Rezultatų aptarimas}

Griuvimą patiria apie trečdalis vyresnių nei 65 metų žmonių. Griuvimų dažnis didejja sulig amžiumi. Griuvimas yra viena dažniausių komplikacijų po insulto: net 73 proc. insultą patyrusių asmenų, grịžę iš stacionaro ị namus, pargriūva per pirmuosius 6 mènesius, o 7 proc. griuvimu ivvyksta per pirmają savaitę po insulto. Riziką griūti didina daugybè fizinių, pažintinių ir psichologinių sutrikimų, kurie turi būti atitinkamai vertinami ir valdomi, kad sumažètu hospitalizuojamų asmenų skaičiai. Griuvimo padariniai yra sunkūs kūno sužalojimai ir psichikos sutrikimai, pablogèjusi gyvenimo kokybė, pailgejjusi hospitalizacijos trukmè, ankstyvas stacionarizavimas ị ilgalaikès priežiūros ar slaugos įstaigas ir padidejusios sveikatos priežiūros išlaidos. Pagrindinès hospitalizacijos dèl griuvimų priežastys yra klubo sąnario lūžiai, galvos smegenų traumos ir viršutinių galūnių sužalojimai. Insulto sukelto griuvimo lūžių dažnis yra net 4 kartus didesnis, nei bendrosios populiacijos. 
Reabilitacijos metu taikomi pusiausvyros lavinimo ar Tai-chi pratimai mažina patyrusių insultą senyvo amžiaus asmenų griuvimo riziką $[8,9,10]$. Taikant specializuotą eisenos lavinimo programą, statistiškai reikšmingos įtakos griuvimų mažèjimui nenustatyta. Yra žemos kokybės įrodymų, kad elektrostimuliacija gali sumažinti griuvimų skaičių, tačiau prieš taikant šį metodą ịprastinejje klinikinèje praktikoje, reikia daugiau ịrodymų [14]. Robotizuota stumdomoji vaikštynė I-Walker pagerina vaikščiojimo efektyvumą ir pusiausvyrą asmenims, sirgusiems lengva ar vidutinio sunkumo insulto forma, todèl pagerẻja eisenos stabilumas ir sumažèja griuvimų skaičius [26].

Asmenų, patyrusių galvos smegenų insultą, griuvimo rizikos mažinimas yra plačiai diskutuotinas klausimas. Nèra bendro sutarimo, kas konkrečiai mažina griuvimo riziką, taip pat nèra bendrujų tyrimo protokolų, todèl gautujų rezultatų lyginti tarpusavyje nederètų, nes ịvairūs autoriai naudoja skirtingas skales bei matavimo metodus, lygina skirtingas grupes, nevienodai vertina griuvimus. Trūksta ịrodymų, leidžiančių daryti išvadas apie priemonių poveikị konkrečioje fazėje po insulto. Trūksta duomenų informuoti gydytojus apie galimas intervencijas, kuriomis siekiama užkirsti kelią griuvimo lūžiams, rehospitalizacijai dèl griuvimo problemų, nepageidaujamiems įvykiams, išvengti neigiamo ekonominių veiksnių poveikio ir gyvenimo kokybès blogejjimo. Šiuo metu nèra pakankamai įrodymų daryti išvadas apie tai, kokị poveiki griuvimų prevencijai turi ergoterapeuto apsilankymas namuose, akinių dèvejimas ar naudojimasis stumdomaja vaikštyne. Visų tyrimų analizèse, susijusiose su aplinkos pritaikymu, įrodymų kokybė labai žema [14]. Griuvimas po insulto yra dažnas reiškinys, tačiau labai mažai aukštos kokybès įrodymų apie sèkmingus būdus mažinti senyvo amžiaus žmonių, patyrusių insultą, griuvimo atvejus. Nèra būtent šiai populiacijai skirtų atsitiktinių imčių kontroliuojamų daugiaveiksnių intervencijų tyrimų [11]. C. Sherrington ir kt. atliktoje metaanalizeje, atliekant tyrimus su senyvo amžiaus žmonėmis, nustatyta, jog ị mankštos programą reikia ịtraukti pusiausvyros treniruotes (atskirai ar kartu su kitomis mankštos rūšimis), pakankamą jų kiekị, trukmę ir dažni (pavyzdžiui, mažiausiai du kartus per savaitę 25 savaites), kad sumažètų griuvimų dažnis [27]. Dar nèra tiksliai apibrèžtas optimalus komponentų derinys, tačiau svarbu ịvertinti judrumą, tualeto poreikius, vaistų vartojimą, regejjimą, sumišimą (demencija ir delyras) bei ortostatinę hipotenziją. Pagalbinių judejjimo priemonių (ramentai ir vaikštynès) pritaikymas, saugios judejjimui aplinkos sukūrimas, aiškūs (vaizdo) ženklai, tinkama avalynè, akiniai ir klausos pagalbos priemonès yra paprasti būdai sumažinti galimą aplinkos poveiki griuvimui [28].

\section{Išvados}

1. Specializuota reabilitacijos programa mažina asmenų, patyrusių galvos smegenų insultą, griuvimų dažnį, tačiau rezultatai yra diskutuotini dèl nepakankamų įrodymų.

2. Asmenims, patyrusiems galvos smegenų insultą, pusiausvyros lavinimo pratimų programa ar Tai-chi pratimai griuvimo rizikai mažinti yra veiksmingi, tačiau dar reikia daugiau ịrodymų.

3. Robotizuota stumdomoji vaikštynė I-Walker ar elektrostimuliacija sumažina griuvimo riziką asmenims, patyrusiems galvos smegenų insultą, tačiau šiems gydymo metodams reikètų detalesnès analizès ir klinikinių tyrimų.

\section{Literatūra}

1. Kumar A, Srivastava DK, Verma A, et al. The problems of fall, risk factors \& there management among geriatric population in India. Indian Journal Community Health 2013;25(2):89-94.

2. Dionyssiotis Y. Analyzing the problem of falls among older people. International Journal General Medicine. 2012;5:805-813. https://doi.org/10.2147/IJGM.S32651

3. Gillespie LD, Robertson MC, Gillespie WJ, et al. Interventions for preventing falls in older people living in the community. Cochrane Database Systematic Reviews 2012;9:CD007146. https://doi.org/10.1002/14651858.CD007146.pub3

4. Moroz A, Bogey RA, Bryant PR, et al. Stroke and neurodegenerative disorders. Stroke: comorbidities and complications. Arch Phys Med Rehabil 2004;85(3):S11-4. https://doi.org/10.1053/j.apmr.2003.11.012

5. Salter KL, Foley NC, Jutai JW, et al. Assessment of participation outcomes in randomized controlled trials of stroke rehabilitation interventions. International Journal Rehabilitation Research 2006;30(4):339-342.

https://doi.org/10.1097/MRR.0b013e3282f144b7

6. Campbell GB, Matthews JT. An integrative review of factors associated with falls during post-stroke rehabilitation. Journal Nursing Scholarship 2010;42(4):395-404. https://doi.org/10.1111/j.1547-5069.2010.01369.x

7. Denissen S, Staring W, Kunkel D, et al. Interventions for preventing falls in people after stroke. Cochrane Database of Systematic Reviews 2019;10:CD008728. https://doi.org/10.1002/14651858.CD008728.pub3

8. Goto Y, Otaka Y, Suzuki K, et al. Incidence and circumstances of falls among community-dwelling ambulatory stroke survivors: a prospective study. Geriatr Gerontol 2019;19(3):240-244. https://doi.org/10.1111/ggi.13594

9. Mansfield A, Schinkel-Ivy A, Danells CJ, et al. Does perturbation training prevent falls after discharge from stroke rehabilitation? A prospective cohort study with historical control. J Stroke Cerebrovasc Dis 2017;26(10):2174-2180.

https://doi.org/10.1016/j.jstrokecerebrovasdis.2017.04.041

10. Ada L, Dean C M, Lindley R. Randomized trial of treadmill 
training to improve walking in community-dwelling people after stroke: the AMBULATE trial. International Journal Stroke 2013;8(6):436-444.

https://doi.org/10.1111/j.1747-4949.2012.00934.x

11. Batchelor F, Hill K, Mackintosh S, et al. What works in falls prevention after stroke? A systematic review and meta-analysis. American Heart Association 2010;47(8):1715-1722.

https://doi.org/10.1161/STROKEAHA.109.570390

12. Indredavik B., Rohweder G., Naalsund E., et al. Medical complications in a comprehensive stroke unit and an early supported discharge service. American Heart Association 2008;39(2)414-421.

https://doi.org/10.1161/STROKEAHA.107.489294

13. Winstein CJ, Stein J, Arena R, et al. Guidelines for adult stroke rehabilitation and recovery: a guideline for healthcare professionals from the American Heart Association/American Stroke Association. Stroke 2016;47(6):e98-e169.

https://doi.org/10.1161/STR.0000000000000098

14. Verheyden GSAF, Weerdesteyn V, Pickering RM, et al. Interventions for preventing falls in people after stroke. Cochrane Database Systematic Reviews 2013;5:CD008728. https://doi.org/10.1002/14651858.CD008728.pub2

15. Foster EJ, Barlas RS, Wood AD, et al. A history of falls is associated with a significant increase in acute mortality in women after stroke. Journal Clinical Neurology 2017;13(4):411-421. https://doi.org/10.3988/jcn.2017.13.4.411

16. Lord SR, Sherrington C, Menz H, et al. Falls in older people: risk factors and strategies for prevention. Australasian Journal Ageing 2009;28(1).

17. Xu T, Clemson L, O'Loughlin K, et al. Risk factors for falls in community stroke survivors: a systematic review and meta-analysis. Archives Physical Medicine Rehabilitation 2018;99(3):563-573. https://doi.org/10.1016/j.apmr.2017.06.032

18. Cameron ID, Dyer SM, Panagoda CE, et al. Interventions for preventing falls in older people in care facilities and hospitals. Cochrane Database Systematic Reviews. 2012;12:CD005465.

19. Miake-Lye IM, Hempel S, Ganz DA, et al. Inpatient fall prevention programs as a patient safety strategy: a systematic review. Ann Intern Med 2013;158:390-396. https://doi.org/10.7326/0003-4819-158-5-201303051-00005

20. Anderson DC, Postler TS, Dam TT et al. Epidemiology of hospital system patient falls: a retrospective analysis. American Journal Medical Quality 2016;31(5)423-428. https://doi.org/10.1177/1062860615581199

21. Pouwels S, Lalmohamed A, Leufkens B, et al. Risk of hip/ femur fracture after stroke. A population-based case-control study. American Heart Association 2009;40(10):3281-3286. https://doi.org/10.1161/STROKEAHA.109.554055

22. Minhas JS. Falls after a stroke. ESO 2019. eso-stroke.org/ falls-after-a-stroke/

23. Sherrington C, Michalef ZA, Fairhall N, et al. Exercise to prevent falls in older adults: an updated systematic review and meta-analysis. Br J Sports Med 2017;51(24):1750-1758. https://doi.org/10.1136/bjsports-2016-096547

24. Taylor-Piliae RE, Hoke TM, Hepworth JT, et al. Effect of Tai Chi on physical function, fall rates and quality of life among older stroke survivors. Archives Physical Medicine Rehabilitation 2014;95(5),816-824.

https://doi.org/10.1016/j.apmr.2014.01.001

25. Andrade SM, Ferreira JJA, Rufino TS, et al. Effects of different montages of transcranial direct current stimulation on the risk of falls and lower limb function after stroke. J Neurological Research 2017;39(12):1037-1043. https://doi.org/10.1080/01616412.2017.1371473

26. Morone G, Annicchiarico R, Iosa M, et al. Overground walking training with the $\mathrm{i}$-Walker, a robotic servo-assistive device, enhances balance in patients with subacute stroke: a randomized controlled trial. J Neuroeng Rehabil 2016;13(1):47. https://doi.org/10.1186/s12984-016-0155-4

27. Sherrington C, Whitney JC, Lord SR, et al. Effective exercise for the prevention of falls: a systematic review and meta-analysis. Journal American Geriatrics Society 2008;56(12)2234-2243. https://doi.org/10.1111/j.1532-5415.2008.02014.x

28. Morris R, O'Riordan S. Prevention of falls in hospital. Clin Med 2017;17(4):360-362. https://doi.org/10.7861/clinmedicine.17-4-360

\section{FALLS IN STROKE PATIENTS IN THE EARLY PERIOD OF REHABILITATION}

\section{G. Tamulytė, L.Varžaitytė}

Keywords: falls after stroke, falls rehabilitation, falls in elderly, stroke, falls

Summary

The aim of the study was to select and analyze scientific publications that assess the possibilities of rehabilitation of persons at risk of falling after a stroke. Material and methods. Data on elderly people at risk of falling after stroke was searched and collected in the newest science publications. The PubMed database search engine was used and results was found using keywords: stroke, falls, falls after stroke, elderly falls, falls rehabilitation. Results. The analyzed cases show that different rehabilitation measures and different assessment methods are used to reduce the frequency of falls. Simple and basic tools such as falls diary are used, as well as various tests, questionnaires, and scales that require the participation and evaluation of professionals. Conclusions. A multifactor intervention program is important for the elderly at risk of falling after stroke. Balance training, complex training and Tai-Chi work most effectively and it is also important to mention the positive effects of robotic servo-assistive device and the benefits of electrical stimulation.

Correspondence to: tamulyte.gabriele@gmail.com

Gauta 2020-04-15 